\title{
Las relaciones públicas estratégicas para generar confianza y reputación [presentación del monográfico]
}

Strategic public relations to foster trust and reputation [monograph presentation]

\section{Coordinadoras científicos / Scientific coordinators}

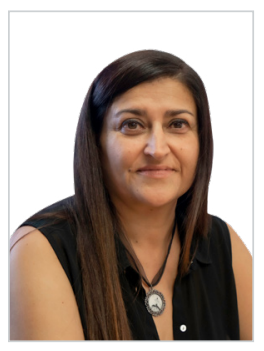

Ma Carmen Carretón Ballester. Profesora Titular del Departamento de Comunicación y Psicología Social de la Universidad de Alicante donde imparte Planificación de las Relaciones Públicas aunque es profesora universitaria desde 1998 y profesora en diferentes másteres desde 2002 hasta la actualidad. Sus líneas de trabajo y aportaciones científicas se desarrollan en el grupo de investigación "relaciones públicas, responsabilidad social y comunicación con minorías" que dirige desde el año 2005 en la Universidad de Alicante. En la actualidad es Vicepresidenta de la Asociación de Investigadores en Relaciones Públicas (AIRP) a la que pertenece desde sus orígenes en 2004, y Co-presidenta del Jurado de los Premios AIRP a la Excelencia Universitaria sobre Relaciones Públicas a los Mejores Trabajos de Grado y de Máster Oficial Universitario desde 2014.

Full Professor in the Department of Communication and Social Psychology at the University of Alicante where she teaches Public Relations Planning although she has been a university lecturer since 1998 and has taught in different master's degree programmes from 2002 to the present. Her work and scientific contributions have been carried out with the research group "Public relations, social responsibility and communication with minorities" which she has been leading since 2005 at the University of Alicante. She is currently Vice President of the Association of Public Relations Researchers (AIRP) to which she has belonged since its inception in 2004, and Co-Chair of the panel of judges for the AIRP Awards for University Excellence in Public Relations for the Best Undergraduate and Master's Degree Projects since 2014.

Universidad de Alicante, España

mc.carreton@ua.es

ORCID: 0000-0002-4851-9683

Palabras clave:

Relaciones públicas; confianza; comunicación estratégica; innovación; reputación.

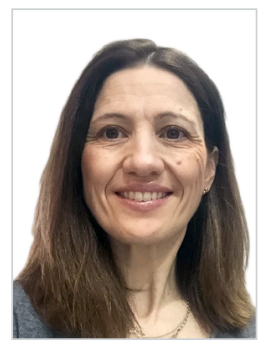

Mónica Viñarás Abad. Profesora Titular del Departamento Comunicación Audiovisual y $\mathrm{Pu}$ blicidad de la Universidad CEU San Pablo (Madrid). Doctora por la Universidad Complutense de Madrid y Premio Extraordinario de Doctorado. Autora de más de cincuenta publicaciones sobre la gestión de las relaciones públicas especialmente en el sector cultural, el desarrollo de la responsabilidad social corporativa o la comunicación digital. Investigadora en varios proyectos de investigación en el Plan Nacional de I+D+i sobre públicos vulnerables. Profesora en grado, máster y doctorado, es directora del Grado en Publicidad y Relaciones Públicas y Coordinadora del Máster en Relaciones Públicas y Organización de Eventos.

Full professor in the Department of Audio-visual Communication and Advertising at CEU San Pablo University (Madrid). She holds a PhD from Complutense University of Madrid and has received the Extraordinary Doctorate Award. Author of more than fifty publications on public relations management, especially in the cultural sector, as well as on the development of corporate social responsibility and digital communication. She has also been a researcher on several investigative projects of the National $R+D+i$ Plan regarding the vulnerable public. Professor of undergraduate, master's and doctoral degrees, she is director of the Degree in Advertising and Public Relations and coordinator of the Master's Degree in Public Relations and Events Organisation.

Universidad CEU San Pablo, Madrid, España

monica.vinarasabad@ceu.es

ORCID: 0000-0001-8792-5927

\section{Keywords:}

Public relations; trust; strategic communication; innovation; reputation.

Cómo citar este artículo / How to cite this article:

Carretón Ballester, Ma . C.; Viñarás Abad, M. (2020). Las relaciones públicas estratégicas para generar confianza y reputación [presentación del monográfico]. Doxa Comunicación, 30, pp. 179-185.

https://doi.org/ 10.31921/doxacom.n30a9 


\section{Presentación}

A pesar de las diferentes denominaciones que desde distintos sectores se quiere conferir a las relaciones públicas, su origen no es que se remonte siglos atrás (Thomas Jefferson en 1802 e incluso, en términos de responsabilidad, en 1827 ya fue utilizado por el reverendo Hoyt), sino que hoy por hoy es una profesión crucial para la gestión del comportamiento de las organizaciones. Prueba de ello es la literatura académica que prolifera desde principios del siglo XIX, y su abundante y mucho más extensa práctica profesional. Desde el conocido trabajo de Edward Bernays, como asesor en diferentes crisis de la industria americana y del enfoque comunicativo innovador de Ivy Ledbetter Lee con su propuesta de conducta responsable para la industria de John Rockefeller, las relaciones públicas han evolucionado sustancialmente. De hecho, a James Grunig se le considera el gran teórico de la profesión y sus aportaciones son referentes entre los notables estudiosos de la Academia. Su Teoría de los Vínculos y la Teoría Situacional de los Públicos sostienen el gran paradigma de la disciplina que venimos enseñando en las aulas universitarias y que también supone el éxito de su praxis profesional y de ingente valor en la actualidad, como muestran las investigaciones de este monográfico.

La reputación y la economía de la confianza son conceptos estrechamente relacionados y de extraordinaria actualidad entre las empresas e instituciones. Sin embargo, ambos son resultado de la estrategia de relaciones públicas, que persiguen influenciar en los públicos a partir de conductas responsables para generar la confianza y lograr la reputación. La comunicación a tal efecto debe ser igual de responsable y coherente con los comportamientos. Informar y comunicar no son lo mismo; en relaciones públicas, informar debe servir para comunicar. Los objetivos de información persiguen dar a conocer un tema y que este sea retenido para abordar los objetivos de motivación que promueven

\section{Presentation}

Despite the variety of names that different sectors want to confer to Public Relations, the importance of its origins is not that it goes back centuries (Thomas Jefferson in 1802, and even in terms of responsibility, it was already being used by Reverend Hoyt in 1827). Instead, nowadays this profession is crucial for managing the behaviour of organisations. Proof of the above is the academic literature that has flourished since the beginning of the nineteenth century, as well as its widespread use and much more extensive professional practice.

Since the time of the well-known work of Edward Bernays, who laboured as a consultant in diverse crises involving American industry, and the innovative, communicative approach of Ivy Ledbetter Lee with his proposal of responsible conduct for John Rockefeller's industry, public relations has evolved significantly. In fact, James Grunig is considered the authoritative theoretician of the discipline, and his contributions are a reference among the outstanding scholars of Academia. His opinions regarding active communication behaviour and the Situational Theory of Publics support the influential paradigm of the discipline that we have been teaching in university classrooms, and represents the success of his professional practice and the enormous value at the present time, as demonstrated by the investigation in this monograph.

Reputation and the economics of trust are closely related concepts and of extraordinary relevance among companies and institutions. However, both ideas are the result of a public relations strategy that seeks to influence the public through responsible behaviour in order to establish trust and achieve reputation. Communication for this purpose must be equally responsible and consistent with behaviour. Reporting and communicating are not the same; in public relations, reporting must serve to communicate. The objective 
formar cogniciones, modificar actitudes y lograr una conducta positiva.

Es de sentido común entonces que la comunicación sea reflejo de su comportamiento. Solo a través de comportamientos responsables con los públicos se conseguirán relaciones basadas en la confianza y en la credibilidad para ganar la reputación merecida.

En los últimos años, acompañando a la industria 4.0, la investigación sobre la planificación de las relaciones públicas sucumbe ante la abundancia de artículos sobre redes sociales o comunicación online. La revolución tecnológica al servicio de las relaciones públicas -con la aparición de nuevos canales para generar y difundir contenidos con un menor control del emisor- no implica que los planteamientos estratégicos sean diferentes, pero sí exige una mayor investigación y continua escucha activa de lo que ocurre con los públicos, mayor inmediatez y una rapidez vertiginosa para ser proactivos. El uso extendido de las redes sociales para comunicar una marca, una identidad o unos valores debe ser entendido como el canal, en su nivel operativo, por el que transmitir los mensajes de interés de los públicos como parte de la estrategia de relaciones públicas. Las herramientas que se emplean (online y offline, internas y externas) no suponen un cambio de estrategia, sino de aplicación táctica de la misma.

$\mathrm{Y}$ esto es fruto de que la praxis de las relaciones públicas se ha ido reconvirtiendo según el momento económico, social y político, según los diferentes comportamientos de los públicos, de sus actores sociales y de sus sociedades a lo largo de la historia y ha sido el mismo desarrollo de la profesión la que ha permitido teorizarla.

En sus inicios, entre 1914 y 1918, la propaganda tenía el propósito de persuadir a los públicos para fines bélicos y políticos utilizando la prensa tradicional para una comunicación unidireccional. En la actualidad, las conductas de of informing is to make a message known, and this message must be retained in order to address the motivational goals that promote cognitive thinking, changes of attitude, and the achievement of positive behaviour.

Therefore, it is common sense to consider that communication should reflect this behaviour. Only through responsible behaviour with the public will relationships of trust and credibility be achieved for the purpose of attaining a deserved reputation.

In recent years, accompanying the 4.0 industry, research on public relations planning has failed to keep up with the abundance of articles on social networks or online communication. The technological revolution at the service of public relations -with the emergence of new channels to generate and disseminate content with less control by the broadcaster-does not imply that strategic approaches are different, but it does demand more research, continuous active listening to what is occurring with audiences, greater immediacy, and dizzying speed in order to be proactive. The widespread use of social networks to communicate a brand, identity or values should be considered the channel at the operational level, through which messages of interest can be delivered to audiences as part of the public relations strategy. The tools used (online and offline, internal and external) do not imply a change in strategy, but instead, they imply tactical application of the strategy.

Moreover, this has resulted from the practice of public relations being gradually transformed according to the economic, social and political moment of the time, as well as to the different behaviours of the public, its social stakeholders, and of their association groups throughout history. In fact, the very development of the profession has allowed it to become theorised. In its beginnings, between 1914 and 1918, propaganda was intended to persuade the public for military and political purposes by using the traditional press for oneway communication. Today, bi-directional and influential 
comunicación bidireccional y de influencia para lograr la confianza mutua entre públicos y organizaciones con las infinitas posibilidades que brindan los medios online y offline, son modelos que imperan en las relaciones entre las organizaciones y sus públicos.

Desde la Gran Depresión en 1929, no habíamos vivido ninguna crisis que hubiera puesto en jaque a los sistemas sanitarios a nivel mundial, creando un grave problema de salud pública y cuyas consecuencias económicas y sociales, de un coste incalculable aún, hacen emerger otras crisis con necesidades diversas e infinidad de públicos que demandan constante información que solucione sus problemas. La comunicación 4.0 exige cada vez más la necesidad de adelantarse a los públicos, y el COVID-19 está haciendo resurgir los paradigmas de la comunicación y la necesidad imperiosa de escuchar a los públicos para tomar decisiones, pero también para decidir qué, cómo y a quién se comunican dichas decisiones, lo que augura importantes aportaciones en las revistas científicas especializadas que teorizarán la gestión de su comunicación y en las que las relaciones públicas coparán, sin duda, su base teórica.

La sociedad en general y los públicos en particular buscan la información de manera activa y, además, son creadores de contenidos. Por lo tanto, se trata no solo de informar, sino de comunicar de manera bidireccional y a razón de las necesidades detectadas desde el compromiso empresarial o institucional con la sociedad. El papel de las relaciones públicas para averiguar las problemáticas y su alcance en los públicos (valores tangibles) es fundamental para gestionar eficazmente la comunicación, generar confianza y ganar reputación (valores intangibles).

En este contexto, los diez trabajos que conforman este monográfico ofrecen una panorámica actual sobre el estudio y la práctica de las relaciones públicas en distintos sectores y desde distintos enfoques: el uso de las redes sociales como canal de comunicación de influencia; el lugar que ocupan communication to achieve mutual trust between audiences and organisations, with the infinite possibilities offered by online and offline media, are models that prevail in the relations between organisations and their audiences.

Since the Great Depression in 1929, we had never experienced a crisis that would have challenged health systems worldwide until COVID-19, which has created a serious public health threat and resulted in economic and social consequences of incalculable cost that cannot yet be quantified, and in turn, this situation has caused other crises to emerge that have also created diverse needs and an infinite number of sectors of the public that demand constant information in order to solve their problems. Communication 4.0 increasingly demands the need to be ahead of the public, and COVID-19 is reshaping communication paradigms and the imperative to listen to the public in order to make decisions, but also to decide what, how and to whom those decisions are communicated, which foretells important contributions in the specialised scientific journals that will offer theories about the management of its communication, in which public relations will undoubtedly monopolise its theoretical basis.

Society in general, as well as particular sectors of the public, actively seek information, but they are also content creators. Therefore, it is not only a matter of disseminating information, but also of communicating in a two-way direction and according to the needs detected from the business or institutional commitment to society. The role of public relations in discovering issues and their scope in reaching audiences (tangible values) is fundamental to effectively managing communication, building trust and gaining reputation (intangible values).

In this context, the ten research works that comprise this monograph offer a current overview of the study and practice of public relations in different sectors and from different approaches: the use of social networks as an influential communication channel; the place of protocol studies 
los estudios de protocolo como herramienta de las relaciones públicas, el valor de los intangibles en la relación que establecen las organizaciones con sus públicos, etc. Participan autores nacionales e internacionales de reconocido prestigio entre los que destacan investigadores referentes en la disciplina como María Teresa García Nieto, Antonio Castillo Esparcia o Andreu Casero Ripollés, entre otros.

En cuanto al contenido y objeto de estudio destaca el protagonismo, en varias de las investigaciones, de la vinculación existente entre las relaciones públicas y los intangibles. La marca, uno de los intangibles más consolidados en la gestión de la comunicación, es protagonista en el artículo de Catalina Osorio Parra y Jaime Alberto Orozco Toro desde Colombia, "La construcción de valores intangibles de marcas de cerveza artesanal. Atributos inmersos en las comunicaciones", donde se relacionan los valores con la estrategia de comunicación y la identidad.

En cuanto a la gestión de la reputación corporativa, la profesora Sonia Ferruz González realiza una revisión del concepto bajo el título "Nueva propuesta de evaluación de la Reputación Corporativa: Indicador de Desempeño Reputacional”, en el que propone un análisis comparativo de las metodologías existentes más reconocidas para evaluar la reputación corporativa, tanto desde el ámbito académico como profesional (monitores de reputación).

Se añade el estudio de otros intangibles en las relaciones como el compromiso ciudadano, con el trabajo "Análisis de los componentes del bien intangible Compromiso Ciudadano en el sector público", de Paloma Piqueiras Conlledo, en el que aborda cómo la Administración Pública ha mostrado cada vez más interés por establecer relaciones de confianza con los ciudadanos. Este texto profundiza en la definición del Compromiso Ciudadano y explica de qué se compone y cómo puede activarse. En esta misma línea, la legitimidad también se revela como un intangible que gestionar en las instituciones públicas a través del estudio as a public relations tool, the value of intangibles in the relationshipthatorganisations establish with theiraudiences, etc. National and international authors of renowned prestige are taking part, among whom are researchers of reference in the discipline, such as María Teresa García Nieto, Antonio Castillo Esparcia, and Andreu Casero Ripollés, among others.

As for the content and object of study, the link between public relations and intangibles stands out in several of the investigations. The brand is one of the most consolidated intangibles in communication management and is the main focus of the article by Catalina Osorio Parra and Jaime Alberto Orozco Toro from Colombia, entitled, "The construction of intangible values in brands of craft beer. Attributes immersed in communication". In this article, values are related to communication strategy and identity.

With regard to the management of corporate reputation, Professor Sonia Ferruz González carries out a review of the concept under the title, "New proposal for the evaluation of Corporate Reputation: Reputational Performance Indicator", in which she proposes a comparative analysis of the most recognised methodologies in existence for evaluating corporate reputation, both from the academic and professional points of view (reputation monitors).

There is also the study of other intangibles in public relations such as citizen engagement, with the work entitled, "Analysis of the components of the intangible asset known as Citizen Engagement in the public sector", by Paloma Piqueiras Conlledo, in which she addresses the way in which Public Administration has shown increasing interest in establishing relations of trust with their citizens. This text delves into the definition of Citizen Engagement and explains its components and how it can be activated. Along the same lines, legitimacy is also revealed as an intangible to be managed in public institutions through the study of both the Ministry, as well as the Minister of Education, Culture and Sport, thanks to Professor Carmen María Robles López. 
del Ministerio y Ministro de Educación, Cultura y Deporte, gracias a la profesora Carmen María Robles López.

La reputación corporativa se estudia en el entorno digital y en el marco de la comunicación política. Amparo López Meri, Silvia Marcos García y Andreu Casero Ripollés analizan las estrategias de comunicación de los principales partidos políticos y sus candidatos a través del contenido en Facebook. En esta línea encontramos también un estudio de la reputación corporativa en redes sociales durante un periodo de crisis, con el artículo de Gema Lobillo Mora y Raquel Gallart Moreno: "Análisis de la crisis reputacional universitaria a través de las redes sociales Twitter y Facebook. Estudio del caso de la Universidad Rey Juan Carlos".

El imparable avance de las redes sociales se refleja en dos artículos más, en este caso centrados en la cultura y el turismo. Se trata de los trabajos de Emelina Galarza Fernández, Eduardo Villena Alarcón y Aimiris Sosa Valcárcel, de la Universidad de Málaga, que investigan la aportación a la gestión de la comunicación y la funcionalidad turística de los museos de Málaga. Por su parte, la propuesta de Francisco Manuel Pastor Marín y Francisco Javier Paniagua Rojano se centra en el uso de la red social Facebook como herramienta de comunicación turística en los grandes destinos urbanos internacionales.

La responsabilidad social corporativa también ocupa el lugar imprescindible que le corresponde. La originalidad de la investigación Graciela Lamouret Colom y María Teresa García Nieto, de la Universidad Complutense de Madrid, reside en estudiar el origen de la comunicación, la humanización, y cómo esta se comunica en un sector tan complejo como el sanitario, concretamente en los hospitales.

Igualmente, disciplinas transversales poco asociadas tradicionalmente a las relaciones públicas, como la creatividad, son objeto de estudio de las profesoras de la Universidad de Valladolid Elena González Leonardo, Marta Pacheco
Corporate reputation has also been addressed in the digital environment and within the framework of political communication. Amparo López Meri, Silvia Marcos García and Andreu Casero Ripollés have analysed the communication strategies of the main political parties and their candidates through their content on Facebook. Along these same lines, we also find a study of corporate reputation on social networks during a crisis in the article written by Gema Lobillo Mora and Raquel Gallart Moreno: "Analysis of the university reputational crisis through the social networks Twitter and Facebook. The Case Study of Rey Juan Carlos University".

The ever-increasing advance of social networks is reflected in two other articles, and in these cases, the focus is culture and tourism. They are the work of Emelina Galarza Fernández, Eduardo Villena Alarcón and Aimiris Sosa Valcárcel, from the University of Malaga, who have investigated the contribution made by the museums of Malaga to communication management and tourist functionality. Francisco Manuel Pastor Marín and Francisco Javier Paniagua Rojano's proposal focuses on the use of the social network Facebook as a tourist communication tool for major international urban destinations.

Corporate social responsibility is also of vital importance. The originality of the research conducted by Graciela Lamouret Colom and María Teresa García Nieto of Complutense University of Madrid can be found in their study of the origin of communication, its humanisation, and how these concepts are disseminated in a field as complex as the health sector, specifically in hospitals.

Likewise, transversal disciplines not traditionally associated with public relations, such as creativity, are the object of a study by University of Valladolid professors Elena González Leonardo, Marta Pacheco Rueda and Belinda de Frutos Torres. The article is entitled, "Dimensions in the evaluation of creativity in integrated communication campaigns. A 
Rueda y Belinda de Frutos Torres. Bajo el título "Dimensiones en la evaluación de la creatividad en campañas de comunicación integrada. Una aportación para la evaluación en el entorno docente", hallamos una orientación hacia las relaciones públicas y su aprendizaje y evaluación en la formación universitaria.

Es de gran interés que la Universidad cuente también con su espacio en este monográfico. En este caso se trata de un artículo que versa sobre la formación en un ámbito muy específico: "Protocolo: análisis de los estudios universitarios oficiales en España”, a cargo de Leticia Rodríguez Fernández y Antonio Castillo Esparcia, que permite conocer la oferta universitaria y sus planes de estudios así como su vinculación con el sector de los eventos.

Se puede concluir que este monográfico aborda esta disciplina de una manera global, ya sea por los contenidos, los autores, la metodología y los ámbitos de aplicación. Todos ellos vienen a reforzar, hoy más que nunca, que las relaciones públicas son una parte fundamental de la estrategia de las organizaciones orientada a establecer relaciones de confianza con sus públicos. contribution for assessment in the educational environment". We find in this study an approach to public relations with regard to how it is learned and assessed in the university environment.

It is of great interest that universities in general have their own space in this monograph as well. In this regard, we present an article that deals with training in a very specific area: "Protocol: analysis of official university studies in Spain", by Leticia Rodríguez Fernández and Antonio Castillo Esparcia, which provides information on the university offering and its study plans, as well as its ties to the events sector.

In conclusion, this monograph takes a comprehensive approach to this discipline, either through the content, authors, methodology, or fields of application. All of these factors, today more than ever, reinforce the concept that public relations is a fundamental part of the strategy of organisations aimed at establishing relationships of trust with their audiences. 